\title{
KAJIAN PENGGUNAAN OKSIDAN OZON PADA PENGOLAHAN LIMBAH CAIR INDUSTRI UDANG
}

\author{
Isyuniarto, Agus Purwadi \\ PTAPB - BATAN Yogyakarta
}

\begin{abstract}
ABSTRAK
KAJIAN PENGGUNAAN OKSIDAN OZON PADA PENGOLAHAN LIMBAH CAIR INDUSTRI UDANG. Telah dilakukan kajian penggunaan ozon pada pengolahan limbah cair industri udang. Tujuan penelitian ini adalah mengkaji pengaruh penggunaan oksidan ozon untuk menurunkan BOD, COD dan TSS dalam limbah cair industri udang. Volume limbah untuk setiap perlakuan sebanyak $500 \mathrm{ml}$, diozonisasi selama 10 menit, dengan variasi pH limbah : 7, 8, 9, 10 dan 11 dengan cara pemberian kapur tohor. Dengan $\mathrm{pH}$ yang optimal kemudian digunakan untuk perlakuan berikutnya, yaitu variasi waktu pemberian ozon : 0, 5, 10, 15, 20, dan 25 menit. Dari percobaan diperoleh data bahwa kondisi yang optimal adalah pada $\mathrm{pH}=9$ dan waktu ozonisasi 20 menit. Pada kondisi ini diperoleh kadar ketiga pencemar sebagai berikut : $B O D=41 \mathrm{mg} / \mathrm{l}, C O D=54 \mathrm{mg} / \mathrm{l}$, dan $\mathrm{TSS}=25 \mathrm{mg} / \mathrm{l}$. Ketiga parameter pencemar tersebut sudah memenuhi ketentuan standat baku mutu limbah cair industri udang menurut Keputusan Menteri Negara Lingkungan Hidup No. Kep. 51/MENLH/10/1995 dan Keputusan Gubenur DIY No. Kep. 281/KPTS/ 1998, sebagai persyaratan limbah golongan III.

Kata kunci : ozon, BOD, COD, TSS, udang.
\end{abstract}

\section{ABTRACT}

STUDY OF USE OZONE OXYDAN AT LIQUID WASTE PROCESSING OF PRAWN INDUSTRY. Study of use ozone oxydan at liquid waste processing prawn industry was done. This research target is to study the influence of utilization of ozone oxydan to degrade the BOD, COD and TSS in liquid waste processing of prawn industrial. Waste volume for every treatment is $500 \mathrm{ml}$, ozonisation time 10 minute, with the variation of $\mathrm{pH}: 7,8,9,10$ and 11 by gift calcify. With $\mathrm{pH}$ optimal then used for the treatment variation of time of ozone gift : 0, 5, 10, 15, 20, and 25 minute. From the experiment it was obtained that the optimal condition is reached at $\mathrm{pH}=9$ and time of ozonisation 20 minute. At this condition is obtained the three following parameters: $B O D=41 \mathrm{mg} / \mathrm{l}, C O D=54 \mathrm{mg} / \mathrm{l}$, and $T S S=25 \mathrm{mg} / \mathrm{l}$. The parameter have pursuant to permanent standart quality of industrial liquid waste processing of prawn according to Decree of The State'S Minister of Environment No. Piece. 51/MENLH/10/1995 and Decision of Gubenur DIY No. 281 / KPTS/1998, as conditions of waste of faction III.

Keyword : ozone, BOD, COD, TSS, prawn

\section{PENDAHULUAN}

Dembangunan yang pesat di bidang ekonomi di satu sisi akan meningkatkan kualitas hidup manusia, yaitu dengan meningkatnya pendapatan masyarakat, tetapi di sisi lain akan berakibat pada penurunan kesehatan akibat adanya pencemaran yang berasal dari limbah industri dan rumah tangga. Hal ini karena kurangnya atau tidak memadainya fasilitas atau peralatan untuk menangani dan mengelola limbah tersebut. Dengan berkembangnya ilmu pengetahuan maka berkembang pulalah industri-industri. Akibatnya lingkungan menjadi salah satu sasaran pencemaran, terutama sekali lingkungan perairan yang terganggu oleh adanya limbah industri, baik industri pertanian, industri pertambangan maupun dari rumah tangga. Banyak dijumpai limbah dibuang ke lingkungan tanpa pengolahan terlebih dahulu.

Saat ini budi daya udang dengan tambak telah berkembang dengan pesat, karena udang merupakan komoditi ekspor yang dapat dihandalkan dalam meningkatkan ekspor nonmigas dan merupakan salah satu jenis biota laut yang bernilai ekonomis tinggi. Udang di Indonesia pada umumnya diekspor dalam bentuk udang beku yang telah dibuang bagian kepala, kulit, dan ekornya. 
Limbah yang dihasilkan dari proses pembekuan udang, pengalengan udang, dan pengolahan kerupuk udang berkisar antara 30\% - 75\% dari berat udang. Dengan demikian jumlah bagian yang terbuang dari usaha pengolahan udang cukup tinggi.(1) Limbah kulit udang mengandung konstituen utama yang terdiri dari protein, kalsium karbonat, khitin, pigmen, abu, dan lain-lain. ${ }^{(1)}$

Meningkatnya jumlah limbah udang masih merupakan masalah yang perlu dicarikan upaya pemanfaatannya. Hal ini bukan saja memberikan nilai tambah pada usaha pengolahan udang, akan tetapi juga dapat menanggulangi masalah pencemaran lingkungan yang ditimbulkan, terutama masalah bau yang dikeluarkan serta estetika lingkungan yang kurang baik.(2) Saat ini di Indonesia, sebagian kecil dari limbah udang sudah dimanfaatkan dalam pembuatan kerupuk udang, petis, terasi, dan bahan pencampur pakan ternak. Sedangkan di negara maju seperti Amerika Serikat dan Jepang, limbah udang telah dimanfaatkan di dalam industri sebagai bahan dasar pembuatan khitin dan khitosan. Manfaatnya di berbagai industri modern banyak sekali seperti industri farmasi, biokimia, bioteknologi, biomedikal, pangan, kertas, tekstil, pertanian, dan kesehatan. Khitin dan khitosan serta turunannya mempunyai sifat sebagai bahan pengemulsi koagulasi dan penebal emulsi. ${ }^{(3)}$

Pengolahan ikan secara tradisional akan menghasilkan limbah yang langsung dibuang ke dalam badan air tempat ikan tersebut hidup. Hal ini tidak akan menimbulkan pencemaran selama debit air limbah dan limbahnya sedikit serta dapat menyebar..$^{(4)}$ Ada 2 jenis limbah dalam industri pembekuan udang, yaitu limbah cair berupa suspensi air kotoran udang dan limbah padat berupa kepala udang, yang keduanya merupakan sumber kontaminan apabila tidak diolah dengan baik. ${ }^{(5)}$

Berdasarkan Peraturan Pemerintah Nomor 82 Tahun 2001 tentang Pengelolaan Kualitas Air dan Pengendalian Pencemaran Air, yang dimaksud dengan air limbah adalah sisa dari suatu hasil usaha dan atau kegiatan yang berwujud cair. Tchobanoglous ${ }^{(6)}$ mendefinisikan bahwa berdasarkan titik sumbernya, air limbah sebagai kombinasi cairan atau air dari limbah yang dihasilkan dari pemukiman, institusi, dan kegiatan komersial dan industri, yang bisa saja bercampur dengan air tanah, air permukaan, dan air hujan. Baku mutu limbah cair pada industri pengolahan hasil perikanan dan baku mutu limbah cair industri pengolahan ikan dan kerangkerangan untuk industri lama atau sudah beroperasi dapat dilihat pada Tabel ${ }^{1^{(4)}}$.

Tabel 1. Baku mutu limbah cair industri pengolahan ikan dan kerang-kerangan untuk industri lama atau sudah beroperasi.

\begin{tabular}{|c|c|c|c|c|c|c|}
\hline \multirow[b]{2}{*}{ Industri Hasil Perikanan } & \multicolumn{2}{|c|}{$\mathrm{BOD}_{5}$ maks. } & \multicolumn{2}{|c|}{ COD maks. } & \multicolumn{2}{|c|}{ TSS maks. } \\
\hline & $\begin{array}{c}\text { Kadar } \\
\mathrm{mg} / \mathrm{l}\end{array}$ & $\begin{array}{l}\text { Beban } \\
\mathrm{kg} / \mathrm{ton}\end{array}$ & $\begin{array}{l}\text { Kadar } \\
\text { mg/ton }\end{array}$ & $\begin{array}{l}\text { Beban } \\
\mathrm{kg} / \mathrm{ton}\end{array}$ & $\begin{array}{l}\text { Kadar } \\
\text { mg/ton }\end{array}$ & $\begin{array}{l}\text { Beban } \\
\mathrm{kg} / \mathrm{ton}\end{array}$ \\
\hline 1. Pengolahan ikan & 150 & 7,5 & 200 & 7,5 & 60 & 3,0 \\
\hline 2. Kepiting/lobster & 150 & 5,0 & 200 & 5,0 & 150 & 5,0 \\
\hline 3. Udang & 300 & 30,0 & 400 & 30,0 & 200 & 20,0 \\
\hline 4. Jenis lain dari kerang & 200 & 10,0 & 270 & 10,0 & 160 & 8,0 \\
\hline 5. Makanan ikan & 280 & 7,8 & 370 & 7,8 & 160 & 4,0 \\
\hline $\begin{array}{l}\mathrm{pH}=6,0-9,0 \\
\text { Debit limbah cair maksimum untu } \\
\text { 1. Pabrik pengolahan ikan } \\
\text { 2. Kepiting/lobster } \\
\text { 3. Udang } \\
\text { 4. Kerang-kerangan } \\
\text { 5. Makanan Ikan }\end{array}$ & $\begin{array}{l}= \\
=50 r \\
=30 \\
=100 \\
=50 \\
=25\end{array}$ & $\begin{array}{l}\text { on bahar } \\
\text { on baha } \\
\text { on baha } \\
\text { on baha } \\
\text { on baha }\end{array}$ & $\begin{array}{l}\text { aku } \\
\text { aku } \\
\text { aku } \\
\text { aku } \\
\text { aku }\end{array}$ & & & \\
\hline
\end{tabular}

Limbah industri pengolahan produk ikan banyak mengandung bahan organik alami yang tidak membahayakan dan mudah terurai (biodegradable pollutan), serta dapat dibuang ke lingkungan perairan. Perombakan limbah bahan organik tersebut terjadi dalam waktu yang relatif lama dan tidak dapat ditentukan 
sehingga supaya air limbah yang akan dibuang ke dalam air tidak melampaui baku mutu lingkungan dan tidak menimbulkan pencemaran air maka limbah tersebut harus dikelola terlebih dahulu.

Salah satu teknologi pengolahan limbah yang ramah lingkungan saat ini adalah teknologi ozonisasi yang akan menghasilkan residu pengolahan berupa air dan $\mathrm{CO}_{2}$. Ozon akan larut dalam air untuk menghasilkan hidroksi radikal $\left(\mathrm{OH}^{-}\right)$. Hidroksi radikal berkekuatan untuk mengoksidasi senyawa organik dan dapat dipergunakan dalam proses sterilisasi berbagai jenis mikroorganisme, menghilangkan bau, dan menghilangkan warna pada limbah cair. Sebagai sampel penelitian adalah limbah cair industri pembekuan udang PT Anugerah, Cilacap dan menggunakan alat ozonizer buatan Lab. Plasma BATAN Yogyakarta.

\section{TATA KERJA}

\section{BAHAN}

Bahan yang dijadikan sampel penelitian adalah kapur tohor, aquades dan air limbah industri pembekuan udang dari PT Anugerah, Cilacap, Jawa Tengah.

\section{ALAT}

pH meter, timbangan, alat penggerus, alat ozonizer dan alat-alat gelas.

\section{CARA KERJA}

Volume limbah cair untuk setiap perlakuan sebanyak $500 \mathrm{ml}$, diozonisasi selama 10 menit, dengan variasi pH limbah : 7, 8, 9, 10 dan 11 dengan cara pemberian susu kapur tohor 2\%. Dari percobaan ini akan diperoleh pH limbah yang optimal, yang kemudian digunakan untuk perlakuan berikutnya, yaitu variasi waktu pemberian ozon : 0, 10, 20, 30, 4050 dan 60 menit. Kemudian hasil perlakuan dianalisis kadar BOD, COD dan TSS-nya. Dari hasil analisis kemudian dibuat grafik pengaruh $\mathrm{pH}$ limbah dan waktu ozonisasi terhadap kadar BOD, COD dan TSS.

\section{HASIL DAN PEMBAHASAN}

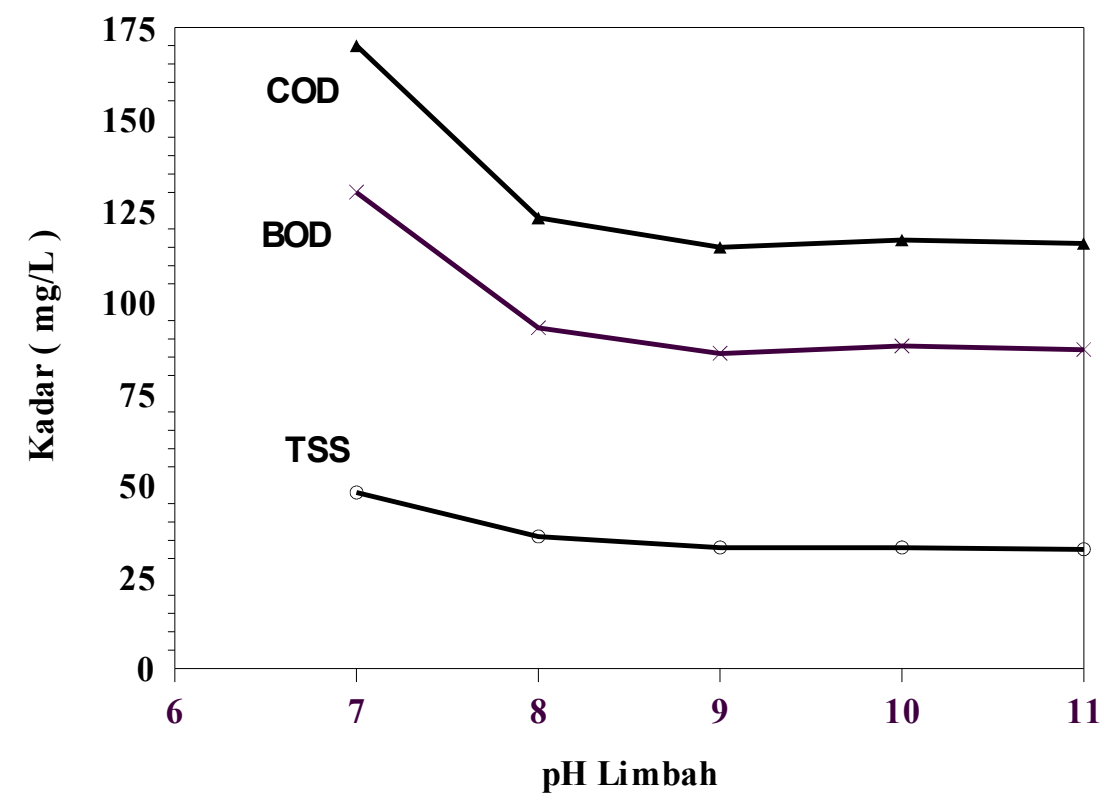

Gambar 1. Pengaruh pH limbah terhadap kadar BOD, COD dan TSS.

Limbah cair organik yang diambil langsung dari kolam pembuangan proses produksi pabrik pembekuan udang mempunyai nilai pH 7,25 dengan kadar BOD $130 \mathrm{mg} / \mathrm{l}$, kadar COD $170 \mathrm{mg} / \mathrm{l}$, dan kadar TSS $48 \mathrm{mg} / \mathrm{l}$. Meskipun kadar ketiga pencemar tersebut masih di bawah baku mutu yang sudah ditentukan (Tabel 1), tetapi karena perombakan limbah bahan organik tersebut terjadi dalam waktu yang relatif lama sebaiknya limbah 
tersebut diproses terlebih dahulu, sehingga tidak akan mencemari badan air. Pengaruh $\mathrm{pH}$ limbah terhadap kadar BOD, COD dan TSS setelah proses ozonisasi dapat dilihat pada Gambar 1.

Pada Gambar 1 tersebut dapat dilihat bahwa semakin tinggi pH limbah maka semakin besar pula penurunan kadar BOD, COD dan TSS yang ada dalam limbah. Hal ini hampir sama dengan penelitian Kristyanto( $^{(7)}$, yang menggunakan sampel limbah medis diketahui bahwa pemberian ozon pada air limbah dengan penambahan larutan kapur $2 \%$ dengan nilai $\mathrm{pH} 9$ dapat menurunkan nilai BOD, COD dan TSS. Kedua hasil penelitian ini menunjukkan bahwa ozonisasi dengan penambahan kapur mampu menurunkan kadar COD air limbah.

Ozon akan membunuh bakteri, sehingga bakteri tidak akan menggunakan oksigen terlarut untuk merombak bahan-bahan organik yang ada dalam air limbah tersebut. Sehingga peran bakteri digantikan oleh ozon yang bersama-sama kapur tohor $(\mathrm{CaO})$ akan menurunkan kadar BOD dan COD, seperti reaksi sebagai berikut ${ }^{(8)}$ :

$$
\begin{aligned}
& \mathrm{C}_{n} \mathrm{H}_{a} \mathrm{O}_{b} \mathrm{~N}_{c}+\left(n+\frac{a}{2}-b-\frac{3 c}{2}\right) \mathrm{O}^{*} \rightarrow \mathrm{n} \mathrm{CO}_{2}+\left(\frac{a}{2}-\frac{3 c}{2}\right) \mathrm{H}_{2} \mathrm{O}+\mathrm{c} \mathrm{NH}_{3} \\
& \frac{1}{a} \mathrm{C}_{a} \mathrm{H}_{b} \mathrm{O}_{c}+\left(\frac{n}{2}+\frac{b}{2 a n}-\frac{c}{a n}\right) \mathrm{O}^{*} \rightarrow \mathrm{CO}_{2}+\left(\frac{b}{2 a}\right) \mathrm{H}_{2} \mathrm{O}
\end{aligned}
$$

Tanpa adanya ozon, kerja kapur $(\mathrm{CaO})$ tidak akan maksimal karena tidak ada unsur yang dapat mengaktifkan ion $\mathrm{OH}^{-}$yang dihasilkan kapur dan ozon membantu ion-ion $\mathrm{OH}^{-}$yang dihasilkan oleh $\mathrm{CaO}$ menjadi lebih aktif (radikal). Ion-ion $\mathrm{OH}^{-}$akan memecah atau merombak bahan-bahan organik yang terdapat dalam air limbah, seperti pada reaksi sebagai berikut :

$$
\begin{aligned}
& \mathrm{CaO}+\mathrm{H}_{2} \mathrm{O} \rightarrow \mathrm{Ca}(\mathrm{OH})_{2} \\
& \mathrm{Ca}(\mathrm{OH})_{2} \rightarrow \mathrm{Ca}^{2+}+\mathrm{OH}^{-}
\end{aligned}
$$

Disamping itu ion $\mathrm{OH}^{-}$ini juga dapat berasal dari reaksi ozon dalam air, seperti pada reaksi sebagai berikut :

$$
\begin{aligned}
& \mathrm{O}_{3}+\mathrm{H}_{2} \mathrm{O} \rightarrow \mathrm{HO}^{+}+\mathrm{OH}^{-} \\
& \mathrm{HO}^{+}+\mathrm{OH}^{-} \rightarrow 2 \mathrm{HO}_{2} \\
& \mathrm{O}_{3}+\mathrm{HO}_{2} \rightarrow \mathrm{HO}+2 \mathrm{O}_{2} \\
& \mathrm{HO}+\mathrm{HO}_{2} \rightarrow \mathrm{H}_{2} \mathrm{O}+\mathrm{O}_{2}
\end{aligned}
$$

Banyaknya ion $\mathrm{OH}^{-}$radikal dan ion $\mathrm{O}^{-}$radikal inilah yang akan mengoksidasi senyawa organik dalam limbah, sehingga BOD, COD dan TSS dalam limbah turun secara signifikan.

Menurut Hatmanto ${ }^{(9)}$, proses ozonisaasi hanya sedikit sekali mempengaruhi penurunan konsentrasi TSS dalam air limbah, karena yang paling berpengaruh pada penurunan TSS adalah pada saat pre-treatment dengan menggunakan bahan koagulan, dalam hal ini digunakan kapur. Reaksi yang terjadi antara kapur dengan air limbah pada proses ozonisasi adalah sebagai berikut :

$$
\begin{aligned}
& \mathrm{CaCO}_{3}-\zeta \rightarrow \quad \mathrm{CaCO}_{3} \text { flok } \\
& \mathrm{CaCO}_{3 \text { flok }} \longrightarrow \mathrm{CaCO}_{3 \text { flok }} \text {. } \\
& \text { (Organik ) }-\zeta \rightarrow\left(\mathrm{CO}_{2}+\mathrm{H}_{2}+\mathrm{O}_{2}\right)+(\text { organik ). } \\
& \mathrm{CaCO}_{3 \text { flok }} .+(\text { Organik }) . \rightarrow \mathrm{CaCO}_{3} \text {----- }(\text { organik })_{\text {flok }} \downarrow
\end{aligned}
$$

Flok-flok inilah yang menyerap partikel-partikel organik yang melayang-layang dalam limbah, sehingga TSS limbah turun.

Air limbah dari proses pembekuan udang banyak mengandung protein karena berasal dari pengolahan bahan baku utama, yaitu udang. Kekeruhan air terjadi karena adanya partikel-partikel yang melayang-layang yang mengandung protein. Protein tersebut diikat dan dipecah menjadi senyawa yang lebih sederhana oleh ozon dan kapur. 


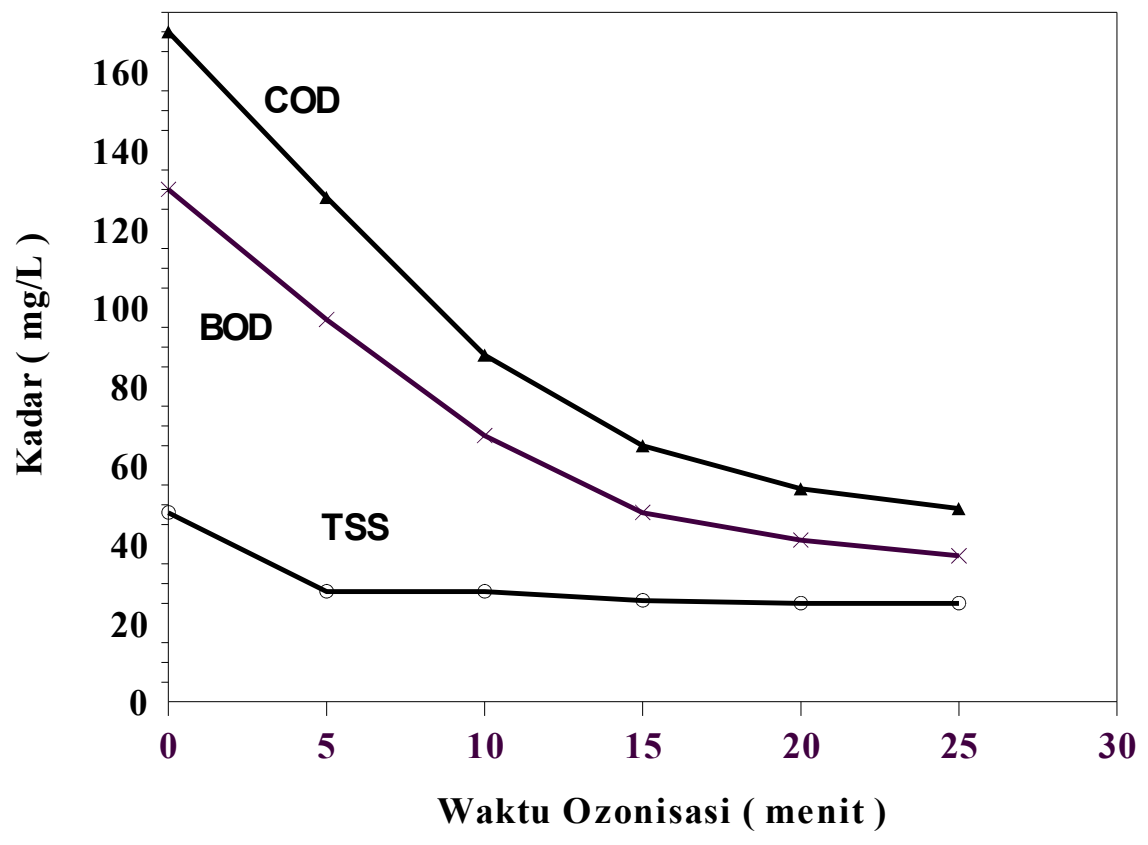

Gambar 2. Pengaruh waktu ozonisasi terhadap kadar BOD, COD dan TSS.

Dari Gambar 2 dapat dilihat, bahwa semakin lama waktu ozonisasi semakin besar pula penurunan kadar BOD, COD dan TSS limbah. Hal ini disebabkan dengan penambahan waktu ozonisasi mengakibatkan jumlah ozon di dalam larutan limbah semakin banyak, sehingga jumlah ion $\mathrm{OH}^{-}$radikal dan ozon yang mengoksidasi zat organik pada limbah juga akan semakin banyak, seperti ditunjukkan pada reaksi nomor (5). Akibatnya semakin banyak zat organik yang teroksidasi, sehingga nilai BOD, COD dan TSS turun. Di samping itu tambahan ion $\mathrm{OH}^{-}$radikal juga dapat berasal dari reaksi kapur dalam air, seperti ditunjukkan pada reaksi nomor (4). Apabila dilihat dari tingkat penurunannya, terlihat ketiga parameter pencemar (BOD, COD dan TSS) turun secara signifikan, setelah pada menit ke 20 penambahan waktu ozonisasi relatif tidak mempengaruhi penurunan kadar pencemar. Pada menit ke 20 efisiensi penurunan BOD sebesar $68,5 \%$, COD sebesar $68,2 \%$ dan TSS sebesar $47,9 \%$.

\section{KESIMPULAN}

Berdasarkan hasil penelitian yang telah diuraikan, maka dapat diambil suatu kesimpulan bahwa :

1. Semakin tinggi pH limbah dan semakin lama pemberian ozon maka kadar BOD, COD dan TSS dalam limbah juga semakin turun. Kondisi yang optimal untuk penelitian ini adalah pada $\mathrm{pH}=9$ dan waktu ozonisasi 20 menit.

2. Pada kondisi optimal tersebut diperoleh kadar ketiga parameter sebagai berikut : $B O D=41 \mathrm{mg} / \mathrm{l}, \mathrm{COD}=54$ $\mathrm{mg} / \mathrm{l}$, dan TSS = $25 \mathrm{mg} / \mathrm{l}$, dengan efisiensi penurunan BOD, COD, dan TSS masing-masing sebesar $68,5 \%$, $68,2 \%$, dan $47,9 \%$.

3. Ketiga parameter tersebut sudah sesuai dengan standar baku mutu limbah cair industri menurut Keputusan Menteri Negara Lingkungan Hidup No. Kep. 51/MENLH/10/1995 dan Keputusan Gubenur DIY No. Kep. 281/KPTS/ 1998

\section{UCAPAN TERIMA KASIH}

Dengan selesainya penelitian ini disampaikan rasa terima kasih kepada Sdri. Ikha Jayanti MU, mahasiswi tugas akhir Fak. Pertanian UGM Yogyakarta dan rekan-rekan teknisi Laboratorium Plasma.

\section{DAFTAR PUSTAKA}

1. ANONIM, Pengolahan dan Pemanfaatan Limbah Hasil Perairan Seri I. Dirjen Perikanan, Jakarta, (1994). 
2. MANJANG, Y., Analisa Ekstrak Berbagai Jenis Kulit Udang Terhadap Mutu Khitosan, Jurnal Penelitian Andalas, V (12)(1993) $138-143$

3. LANG, G., Chitosan Derivatives-Preparation and Potential Uses, Collection of working Papers 28, Universiti Kebangsaan Malaysia, 11 : (1995) $109-114$

4. SAHUBAWA, LATIF dan AMIR HUSNI. 2004. Manajemen Limbah Industri Perikanan, Jurusan Perikanan Fakultas Pertanian, Universitas Gadjah Mada, Yogyakarta, (2004).

5. NURJALI, "Kemampuan Batu Gamping dan Karbon Aktif dari Tempurung Kelapa sebagai Media Saring dalam Menurunkan Kadar Total Suspended Solid dan Biological Oxygen Demand pada Limbah Cair Industri Pembekuan Udang PT Dharma Niaga Kabupaten Cirebon", Skripsi, Fakultas Kesehatan Masyarakat Universitas Diponegoro, Semarang, (2001).

6. TCHOBANOGLOUS, G., F.L. BURTON, H.D. STENSEL, Wastewater Engineering : Treatment and Reuse. McGraw Hill Company, New York, (2003).

7. KRISTYANTO, T.D., "Pengolahan Limbah Cair Rumah Sakit Umum Daerah Kota Yogyakarta dengan Menggunakan Teknologi Ozon dan Kapur". Tugas Akhir S-1 Jurusan Teknokimia Nuklir, STTN-BATAN, Yogyakarta, (2006).

8. ISYUNIARTO, " Aplikasi ozonizer pada industri, kesehatan dan lingkungan ", Laporan Intern, Disajikan dalam Presentasi dan Sosialisasi Aplikasi ozonizer pada industri, kesehatan dan lingkungan, PMBI-BATAN, Serpong, 7 November 2005

9. HATMANTO, BPD., "Penurunan Kadar BOD, COD, dan TSS Limbah Pabrik Tahu dengan Metode Ozonisasi (Studi Kasus Pabrik Tahu Sari Putih Klaten)", Tugas Akhir S-1, Fakultas Teknik Lingkungan, UNDIP, Semarang, (2006). 